\title{
Survey of customer expectation and satisfaction: preliminary research of a modular product design approach for sheep cage design
}

\author{
Yuli Agusti Rochman ${ }^{1, *}$ and Dwi Ana Ratna Wati ${ }^{2}$ \\ ${ }^{1}$ Industrial Engineering Department, Universitas Islam Indonesia, Indonesia \\ ${ }^{2}$ Electrical Engineering Department, Universitas Islam Indonesia, Indonesia
}

\begin{abstract}
This study aims to produce a modular sheep cage design. Feeding, maintenance and integrated waste management are taking into account in the design. The modular and integrated product design provides advantages such as (1) easy way of making and modifying the product, (2) enabling the utilization of existing facilities such as shade, (3) giving the user a sense of convenience as the waste can be processed and not being a source of pollution. The Modular Quality Function Deployment (QFD) method is applied to identify modules associated with the customer needs of the product. A survey about customer expectation and satisfaction was conducted in order to evaluate the gap of both. The highest value of gap between customer expectation and satisfaction of products indicates that the customer needs are the focus of the problems. The most important customer needs are considered in modification and improvement of design. These are (1) the cage is not easy to fall down, (2) the sheep cage can last for long time, (3) it uses a strong frame, (4) the roof section materials is not easy to leak, and (5) It can be used even if one part of the cage is damaged.
\end{abstract}

\section{Introduction}

The development of technology is currently growing rapidly and precisely in creating innovative products in the future [7]. Technology is a special combination of knowledge, productive resources, input, and systematic services to produce the desired output [6]. The use of technology can help improve the efficiency and effectiveness of resource management. Quality function deployment (QFD) process is generally used as customeroriented quality management and product development methodology in the manufacturing industry [1].

For rural communities livestock such as buffaloes, beef cattle, dairy cows, goats, sheep, ducks or domestic poultry have a strategic role because the animals can be used as life savings as well as labor source such as buffaloes and beef cattle. Livestock can also be used as a producer of organic fertilizer which is very good for increasing agricultural production. In addition, having many cattle will improve the social status. Problems related to livestock are public complaint about the adverse effects of livestock business activities because most farmers ignore the handling of waste from their business, some even dump their business waste into the river, resulting in environmental pollution. Livestock waste generated by livestock activities such as feces, urine, and feed residues cause pollution that trigger protests from nearby resident.

To overcome these problems, the role of technology used to make sheep cage. This study proposes a method of designing a modular sheep cage based on QFD. The design takes into account the integrated feeding, maintenance and waste management.

\section{Research methods}

This work is in the context of modular product design. In order to collect information about customer need dealing with sheep cage design, a survey was conducted. The survey includes several stages: (1) define the modularity of the sheep cage as the basis for establishing questions of the survey, (2) making and retrieving the questionnaire data, (3) processing the data with the QFD methodology. The object of this research is sheep cage. The number of respondents is 29 people. Research data was obtained from the survey to farmers in Turi, Sleman, Yogyakarta, Indonesia. The purpose of this survey is to collect information about customer expectation and satisfaction.

\section{Results and discussion}

\subsection{Product modularity}

The division of the product into an independent component raises the modularity. This independence allows companies to create variations of products and standardize components. Product modularity is frequently stated as a goal of good design practice, yet has not been as carefully studied as some other current design practices such as design-for-assembly [8]. Modularity is the focus

\footnotetext{
* Corresponding author: gusti@uii.ac.id
} 
of the company's attention along with improvement efforts to rationalize the product line and to provide increasing varieties at a lower cost. Modularity arises from the division of a product into independent components, allowing companies to standardized components and create product variety. Product modularity is defined using two characteristics; (1) Similarity between the physical and functional architecture of the design and (2) Minimization of the degree of interaction between physical components [3].

Modular design is built on the basis of functional analysis of a product with the same function or with different functions, but has different specifications and performance. [4]. This is achieved by dividing and designing a series of general function modules, select and combine these modules to meet the requirements of the customers. Sheep cage is divided into 4 modules: sheep's house, cage roof, feeding basket, and waste basket. sheep's house is function to manage the sheep. Cage roof is function as protection from sun light and rain. Feeding basket is function as module for feeding and drinking of sheep. Waste basket is function as waste collector from the sheep such as feces and urine.

\subsection{Quality Function Deployment (QFD)}

Quality Function Deployment (QFD) is a method used for the planning and development of structured products that enable the development team to clearly determine the needs and wants of consumers, and evaluate each desired product or service capacity systematically provided to meet the wants and needs Consumers [2]. In general, QFD as a planning tool that is used to meet the sounds of consumers in the form of desires (expectations) and consumer needs. QFD will be used to translate the voice of consumers from the form of specific needs into the direction then engineering actions are disseminated through product planning, part, process planning, production planning, and service [5]. Customer voice are obtained by surveying the customers [4]. We measured the severity of customer's perception items/questions using likert scale (1 to 5). The customer voice of Sheep Cage are presented in Table 1. These are used to identify the customer expectation and satisfaction which then collected by survey. Result of the survey are shown by Table 2. The table has been sorted by the highest gap values. The largest gap is given by the question "The cage is not easy to fall" with a value of 0.83 while smallest gap is "The roof of the cage is made flexible to be removed or installed as needed". From this survey result, we leverage five most important customer need to be consider in the modular design of sheep cage. These are (1) the cage is not easy to fall down, (2) the sheep cage can last for long time, (3) it uses a strong frame, (4) the roof section of the cage uses materials that is not easy to leak, and (5) the cage still can be used even if one part of the cage is damaged.
Table 1. Customer voice

\begin{tabular}{|c|c|}
\hline No & Customer requirements \\
\hline 1 & Easy to maintain \\
\hline 2 & Clean \\
\hline 3 & Durable \\
\hline 4 & Wide \\
\hline 5 & No smell \\
\hline 6 & Can be dismantled pairs \\
\hline 7 & Safe \\
\hline 8 & Strong \\
\hline 9 & Easy to access \\
\hline 10 & Sufficient amount of light \\
\hline 11 & Smooth air circulation \\
\hline
\end{tabular}

Table 2. Survey result of customer expectations and satisfaction

\begin{tabular}{|c|c|c|c|c|}
\hline No & Survey questions & $\begin{array}{l}\text { Exp } \\
\text { ect. }\end{array}$ & $\begin{array}{l}\text { Satisf } \\
\text { ac. }\end{array}$ & Gap \\
\hline 1 & $\begin{array}{l}\text { The cage is not easy to fall } \\
\text { down }\end{array}$ & 4.59 & 3.76 & 0.83 \\
\hline 2 & $\begin{array}{l}\text { The sheep cage can last for } \\
\text { long time }\end{array}$ & 3.90 & 3.17 & 0.72 \\
\hline 3 & Use a strong frame & 4.34 & 3.72 & 0.62 \\
\hline 4 & $\begin{array}{l}\text { The roof section of the cage } \\
\text { uses a material that is not } \\
\text { easy to leak }\end{array}$ & 4.28 & 3.69 & 0.59 \\
\hline 5 & $\begin{array}{l}\text { the cage still can be used } \\
\text { even if one part of the cage } \\
\text { is damaged }\end{array}$ & 3.69 & 3.21 & 0.48 \\
\hline 6 & The cage is made light & 2.83 & 3.24 & 0.41 \\
\hline 7 & $\begin{array}{l}\text { The roof section of the cage } \\
\text { uses a lot of material to } \\
\text { absorb light }\end{array}$ & 3.62 & 3.21 & 0.41 \\
\hline 8 & The cage is easy to clean & 4.17 & 3.79 & 0.38 \\
\hline 9 & $\begin{array}{l}\text { Easy when picking up solid } \\
\text { or liquid waste }\end{array}$ & 4.21 & 3.83 & 0.38 \\
\hline 10 & $\begin{array}{l}\text { Solid and liquid waste can } \\
\text { be separated automatically }\end{array}$ & 4.41 & 4.07 & 0.34 \\
\hline 11 & It is easy to move (portable) & 2.48 & 2.83 & 0.34 \\
\hline 12 & $\begin{array}{l}\text { The roof section of the cage } \\
\text { is made tilted }\end{array}$ & 4.07 & 3.79 & 0.28 \\
\hline 13 & $\begin{array}{l}\text { It is easy to unloaded as } \\
\text { needed }\end{array}$ & 2.62 & 2.86 & 0.24 \\
\hline 14 & It has good air circulation & 3.97 & 3.72 & 0.24 \\
\hline 15 & $\begin{array}{l}\text { It is easy to supplay water } \\
\text { for sheep }\end{array}$ & 3.24 & 3.00 & 0.24 \\
\hline 16 & $\begin{array}{l}\text { The cage floor is arranged } \\
\text { to keep the sheep from } \\
\text { falling easily }\end{array}$ & 4.00 & 3.76 & 0.24 \\
\hline 17 & The cage is made on stage & 4.45 & 4.24 & 0.21 \\
\hline 18 & Material price is cheap & 2.90 & 2.72 & 0.17 \\
\hline
\end{tabular}




\begin{tabular}{|l|l|c|c|c|}
\hline 19 & $\begin{array}{l}\text { The size of the sheep cage } \\
\text { can contain at least 4 sheeps }\end{array}$ & 2.83 & 2.72 & 0.10 \\
\hline 20 & $\begin{array}{l}\text { Where sheep food can be } \\
\text { removed when they want to } \\
\text { be cleaned }\end{array}$ & 2.83 & 2.90 & 0.07 \\
\hline 21 & $\begin{array}{l}\text { The roof of the cage is } \\
\text { made flexible to be } \\
\text { removed or installed as } \\
\text { needed }\end{array}$ & 2.69 & 2.69 & 0.00 \\
\hline
\end{tabular}

\section{Conclusion}

In this paper, modular QFD is apply to developing sheep cage and to know the design parameters that are important to the customer. A sheep cage is divided into 4 modules: sheep's house, cage roof, feeding place, and waste place. The five most important customer needs are considered into modification and improvement of the design. These parameters are the cage is not easy to fall, the sheep cage can last a long time, use a strong frame, the roof section of the cage uses materials that are not easy to leak, and the cage still can be used even if one part of the cage is damaged.

The authors would like to thank DP2M Dikti who has provided financial support for this research project and the reviewers for their great work and their suggestions and recommendations to improve this paper.

\section{References}

1. Z. Baran, M.S. Yıldiz, Quality Function Deployment and Application on a Fast Food Restaurant, International Journal of Business and Social Science, 122-131 (2015)
2. L. Cohen, Quality Function Deployment: How to Make QFD Work for You. Addison-Wesley. (1995)

3. G. Erixon, Modular function deployment: a method for product modularisation. Royal Inst. of Technology, Department of Manufacturing Systems, Assembly Systems Division. (1998)

4. Y. Liu, S.K. Ong, A.Y.C. Nee, Modular Design of Machine Tools to Facilitate Design for Disassembly, Procedia CIRP, 15, 443-448. https://doi.org/10.1016/j.procir.2014.06.085. (2014)

5. A. Rahman, H. Supomo, Analisa Kepuasan Pelanggan pada Pekerjaan Reparasi Kapal dengan Metode Quality Function Deployment (QFD). Jurnal Teknik ITS, 1(1), G297-G302, (2012)

6. Reijntjes, C., Haverkort, B., \& Waters-Bayer, A.. Pertanian masa depan: pengantar untuk pertanian berkelanjutan dengan input luar rendah. Kanisius. (1999)

7. P. Tursch, C. Goldmann, R. Woll, Integration Of Triz Into Quality Function Deployment. Management and Production Engineering Review, 6(2), 56-62. https://doi.org/10.1515/mper-2015-0017, (2015)

8. K. Ulrich, Fundamentals of product modularity. In Management of Design, (pp. 219-231), Springer, (1994) 